International Research Journal of Management, IT \& Social Sciences
Available online at https://sloap.org/journals/index.php/irjmis/
Vol. 6 No. 5, September 2019, pages: 226 233
ISSN: 2395-7492
https://doi.org/10.21744/irjmis.v6n5.733

\title{
A Comparative Study of Mawasangka and Wakatobi Language in South East Sulawesi
}

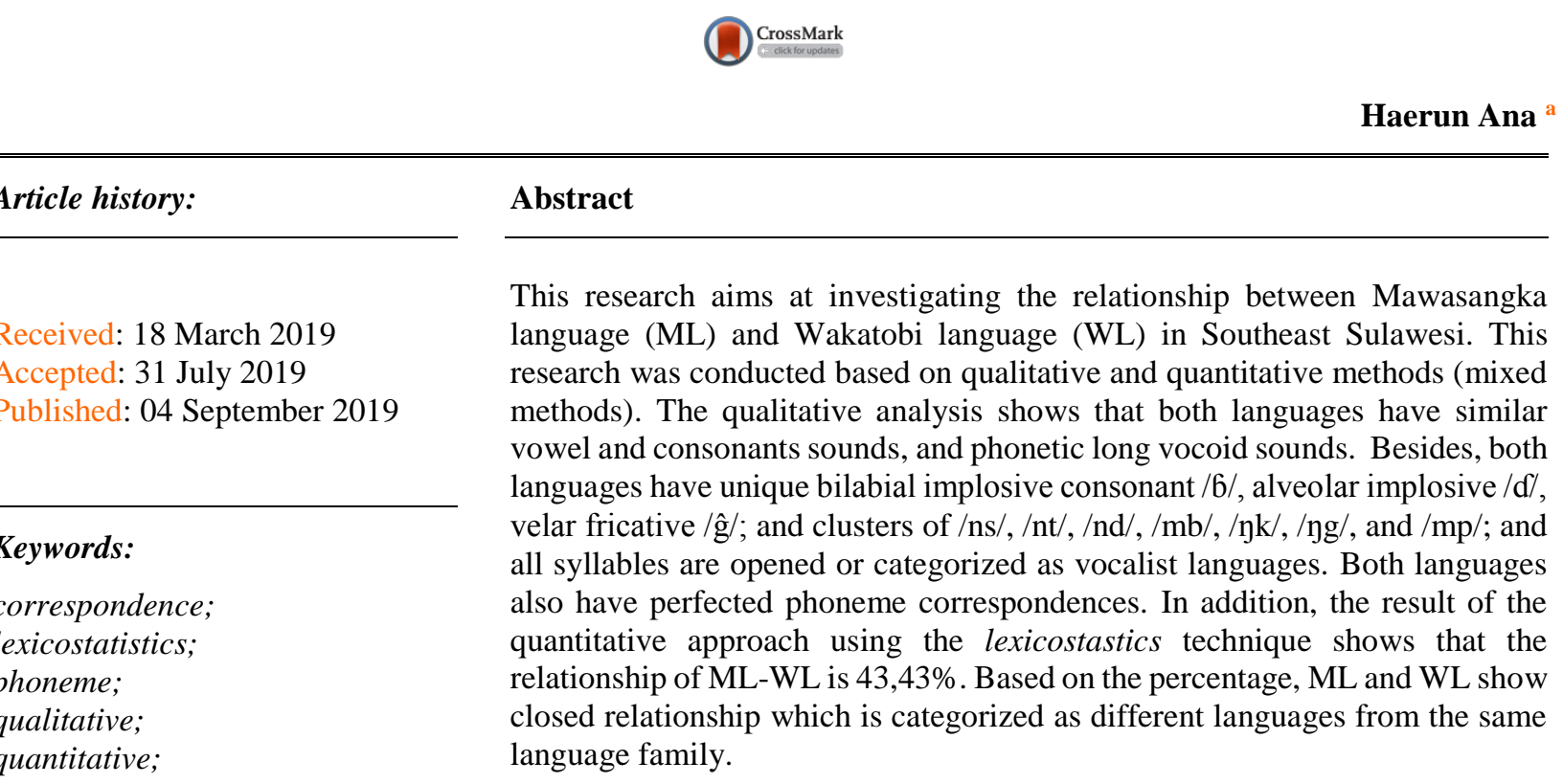

2395-7492@ Copyright 2019. The Author. This is an open-access article under the CC BY-SA license (https://creativecommons.org/licenses/by-sa/4.0/) All rights reserved.

\author{
Author correspondence: \\ Haerun Ana, \\ Haluoleo University, Kendari, South East Sulawesi, Indonesia \\ Email address: liningzan@gmail.com
}

\section{Introduction}

Language is one of the characterizations which is actualized by human being only. Besides, language is one of community signers that is very crucial because it constitutes a tool to know the changing and give description of the activity in the past. Indonesian archipelago, from Sabang to Merauke, consists of various kinds of ethnic groups. Those ethnic groups have their local languages that are different one another. Therefore, beside Indonesian language as the national language, it also has many regional languages which still have been kept and used by every speech community. Every regional language has very important role in daily interaction, particularly in an informal situation to show their appreciation or friendship to other people who come from the same ethnic group. It should also be realized that regional languages have very important role especially in the development of Indonesian language because many Indonesian language vocabularies or words derived from regional language vocabulary.

a Haluoleo University, Kendari, Indonesia 
In this case, languages in Southeast Sulawesi have became the interesting object for the researchers since it is very unique and various. Likewise, Wakatobi and Mawasangka are two languages of Southeast Sulawesi that are not investigated yet maximally and deeply by the previous researchers, mainly in comparative linguistics point of view. Comparative linguistics study has an important role in building community awareness development, maintenance and enlightenment of solidarity understanding, integrity to reach sense of belonging, particularly for the users of the languages compared. In compared languages can be found not only differences but also similarities in terms of the phonology, morphology, and syntactic aspects.

Mawasangka is a language used in Centre Buton Regency. It is used in their daily conversation, either in a formal or informal situation, such as in school, in the office, and in household environment. Likewise, Wakatobi is a language used in Wakatobi Regency (Tukang Besi Island). In last period, Wakatobi language is called as Tukang Besi language (Keraf, 1991). Another name of Wakatobi is Pulo language. Nowadays, the language is more known with the name of "Wakatobi". "Wakatobi" is more popular for societies either in or out of Wakatobi Regency. Besides, this language is categorized as language family of Suai that consists of Wanci, Kaledupa, Tomia, and Binongko dialects (Taalami, 2008). The name of Wakatobi is an abbreviation of Wangi-Wangi, Kaledupa, Tomia, and Binongko islands that constitutes four small islands in Wakatobi Island.

Mawasangka and Wakatobi have similarity development history, mainly in the Buton kingdom and Sultanate period, in which they are authority areas of Buton Sultanate. Even, before 2003, Mawasangka and Wakatobi are included in the administration of Buton Regency. Today, they are as a regency in itself, namely Mawasangka in Center Buton Regency and Wakatobi in Wakatobi Regency. Therefore, a linguistics comparative study of Mawasangka and Wakatobi is very relevant to be conducted. Based on the background and problem above, this research aims at (1) describing the phonemes of Mawasangka and Wakatobi languages and (2) describing the phoneme correspondence and cognate percentage of Mawasangka and Wakatobi languages.

\section{Theoretical Foundation}

The essence language is arbitrary. In which, the language is always changing either internal or external. In other words, the changing of language is general phenomena and it has happened to all languages. Crowley (1992), states that all languages change over time and the different languages tend to change in remarkably similar ways. Besides that, Kooij (1994), states that a study of language change will make us more understanding about the essence of language. Therefore, we can recognize certain languages before languages are changed.

Further, Language is a communication tool that often undergoes changes related to the changes in the around environment either internal or external changes in term of phonology, morphology, syntax, and lexicon (Poedjosoedarmo, 2008; Yani et al., 2018). A hypothesis shows that the similarity of several languages does not happen suddenly or without reasons. It shows that those languages that have several similarities must have altogether development history. It can be known through quantitative approach with similarity percentage count of cognates from languages compared. Crowley \& Claire (2010), gives relationship difference levels of family languages in lexicostatistic technique based on cognate percentage as in the table below.

Table 1

The relationship of cognate percentage

\begin{tabular}{ll}
\hline Level of Subgrouping & Cognate Percentage (\%) \\
\hline Dialects of a language & $81-100$ \\
Languages of a family & $36-81$ \\
Families of a stock & $12-36$ \\
Stocks of micropylum & $4-12$ \\
Microphyla of a mesophylum & $1-4$ \\
Microphyla of a macrophylum & $0-1$ \\
\hline
\end{tabular}

The quantitative percentage uses a certain formula to know the cognate percentage of both languages by using lexicostatistics technique. The formula is as follows:

$$
\frac{(\mathrm{S} x 100)}{\mathrm{n}}=\mathrm{d} \%
$$

Ana, H. (2019). A comparative study of Mawasangka and Wakatobi language in South East Sulawesi. International Research Journal of Management, IT and Social Sciences, 6(5), 226-233. https://doi.org/10.21744/irjmis.v6n5.733 
Information:

$\mathrm{S} \quad=$ the number of isogloss

$\mathrm{n} \quad=$ the number total of words used in the study

$\mathrm{d} \%=$ cognate percentage

In addition, lexicostatistics just uses the words with assumptions as given by Dyen (2018); Lehmann (2013); Bynon (1979); and Keraf (1991), namely:

a) Several words of a language do not change easily.

b) Base words get retention for all time.

c) The change of base words of all language is similar.

This study also discusses the sounds of language, mainly Mawasangka and Wakatobi languages. Each language is signed with sound. Language sound is studied in phonology aspect. In other words, phonology is one of the linguistic branches that study, analyze, and talks about human language sounds. Chaer (2003), divides the term of phonology into two parts, namely phone which means 'sound' and logy which means 'science or knowledge'. So, phonology is knowledge of sound.

Furthermore, Hafsah (2017), classifies language sounds in seven ways. They are (1) vowel, consonant, and semivowel, (2) nasal and oral, (3) fortes and lenses, (4) long and short sound, (5) single and double sounds, (6) voice and voiceless sounds, and (7) exgressive and ingressive sounds). Besides, in phonology study is also introduced suprasegmental sounds are pitch, stress, and juncture.

Phonemes as the main object in this study talk about phoneme system of a language. Finegan (1992), defines phoneme as the sound unit on which all these contrasts depend is. In addition, the phoneme is generally divided into four parts, namely vowel phoneme, consonants phoneme, cluster, and diphthong. However, phoneme can be classified only in two big parts are vowel and consonant sounds.

\section{Materials and Methods}

The data collecting was done through interviewing method (Sudaryanto, 1993; Mahsun, 1995). The interview was carried out by visiting all of the research locations and did the interview through the question lists provided.The collected data was then tabulated and analyzed based on the sequences of the objectives of the study. It was analyzed synchronically using apportioned and interlingua equal methods (Sudaryanto, 1993; Ino et al., 2017).

This study analyzes firstly the phonemes of Mawasangka and Wakatobi, and compared it, either the similarity or difference. To reach the second objective of this study, it used phoneme correspondence between Mawasangka and Wakatobi languages. It s done to give additional evidence qualitatively of the closed relationship between Mawasangka and Wakatobi languages. Next, to find out the cognate percentage of Mawasangka and Wakatobi languages, 200 of Swadesh list used to count the cognate percentage of both languages. The resemblance of meaning and form as the criteria that the words are cognate and not loan words.

\section{Results and Discussions}

This unit describes (1) the phonemes of Mawasangka and Wakatobi languages, (2) the phoneme correspondence between Mawasangka and Wakatobi, and (3) and the cognate percentage of Mawasangka and Wakatobi languages.

\subsection{The Phonemes of Mawasangka and Wakatobi Languages}

The phonemes include vowel and consonant distributions in the initial, medial, and final position.

a) Phonemes of Mawasangka Languages

Based on data analysis result collected in the field, Mawasangka language has five vowel phonemes are /i/, /u/, /e/, /o/, and /a/. The vowel phoneme distribution phonemes of Mawasangka language can be seen below. 
Table 2

Vowel Phoneme Distribution of Mawasangka Language

\begin{tabular}{lllll}
\hline No. & Phoneme & Initial & Medial & Final \\
\hline 1 & /a/ & /ala/ 'take' & /harabu/ 'dust' & /lima/ 'hand' \\
2 & /i/ & /ida/ 'father' & /pogira/ 'fight' & /kadadi/ 'animal' \\
3 & /u/ & /unteli/ 'egg' & /punda/ 'tail' & /harabu/ 'dust' \\
4 & /e/ & /elu/ 'spittle' & /unteli/ 'telur' & /fetinke/ 'hear' \\
5 & /o/ & /olu/ 'cloud' & /fohou/ 'minum' & / bunsolo/ 'eye' \\
\hline
\end{tabular}

The examples on table 2 show that the distribution of vowel phonemes categorized as completed distribution since it may have existed in the initial, medial, and final position. Besides, vowel /a/ sometimes realized as [a:] as allophone of phoneme /a/, such as in words neta: 'fine' and na:mai 'where'. Likewise, phoneme /o/ sometimes realized as [o:], such as in words no:mu 'dive' and kakodo: 'far'; phoneme /i/ sometimes realized as [i:] such as in words $i: n o h a n d o$ 'bowel' and mi:ina 'not'; phoneme /e/ sometimes realized as [e:] such as in words ne: 'nose' and ne:ntu 'right'; and phoneme /u/ sometimes realized as [u:] such as in word tolobu: 'back'. The mark (:) after vowel sound shows as long sound. The realization of the long sound on Mawasangka is not phoneme, instead of phonetics only. In communication, the short and long sound pronounced by the speaker does not disturb or influence the meaning or understanding of utterances. It seems to as idiolect collective at the place that causes the stress or maintenance of vowel tempo when pronounced. So, it creates a long vowel sound.

Related to consonant, Mawasangka language has 20 consonant phonemes are /b/, /b/, /p/, /d/, /d/, /t/, /g/, /g/, /k/, $/ \mathrm{m} /, / \mathrm{n} /, / \mathrm{y} /, / \mathrm{f} /, / \mathrm{s} /, / \mathrm{h} /, / 1 /, / \mathrm{r} /, / \mathrm{y} /$, and /w/, and 7 clusters are /ns/, /nt/, /nd/, /mb/, /yk/, /ng/, and /mp/. The consonant phoneme and cluster distribution of Mawasangka language can be seen in the table (3) below.

Table 3

Consonant Phoneme and Cluster Distribution of Mawasangka Language

\begin{tabular}{|c|c|c|c|c|}
\hline No. & Phoneme & Initial & Medial & Final \\
\hline 1 & /b/ & /buku/ 'bone' & /robine/ 'woman' & - \\
\hline 2 & $/ d /$ & /dudulane/ 'push' & /dudulane/ 'push' & - \\
\hline 3 & /f/ & /fetinke/ 'hear' & /nifi/ 'dream' & - \\
\hline 4 & /g/ & /gunu/ 'mountain' & /pogira/ 'fight' & - \\
\hline 5 & $/ \mathrm{h} /$ & /harabu/ 'dust' & /ĝaha/ 'salt' & - \\
\hline 6 & $/ \mathrm{k} /$ & /kokita/ 'dirty' & /buku/ 'bone' & - \\
\hline 7 & $/ 1 /$ & /lima/ 'five' & /kuli/ 'skin' & - \\
\hline 8 & $/ \mathrm{m} /$ & /mannge/ 'fussy' & /kema/ 'left' & - \\
\hline 9 & $/ \mathrm{n} /$ & /ne:/ 'nose' & /tunu/ 'burn' & - \\
\hline 10 & $/ \mathrm{p} /$ & /poyke/ 'ear' & /sapu/ 'sewing' & - \\
\hline 11 & $/ \mathrm{r} /$ & /raya/ 'thin' & /pogira/ 'fight' & - \\
\hline 12 & $/ \mathrm{s} /$ & /sapu/ 'sewing' & /busoe/ 'blow' & - \\
\hline 13 & $/ \mathrm{t} /$ & /tunu/ 'burn' & /kokita/ 'dirty' & - \\
\hline 14 & /w/ & /waane/'give' & /gawu/ 'smoke' & - \\
\hline 15 & $/ y /$ & /yolu/ 'cloud' & /rankaya/ 'rich' & - \\
\hline 16 & $/ 6 /$ & /6ala/ 'big' & /wo6a/ 'mouth' & - \\
\hline 17 & $/ \mathrm{d} /$ & /dudu/ 'push' & /bada/ 'body' & - \\
\hline 18 & $/ \hat{\mathrm{g}} /$ & /ĝaha/'garam' & /puĝu/ 'stem' & - \\
\hline 19 & $/ \mathrm{j} /$ & & /ijo/ 'green' & \\
\hline 20 & $/ \mathrm{y} /$ & /yawu/ 'cook' & /tinala/ 'ear' & - \\
\hline 21 & $/ \mathrm{jk} /$ & /ykoha/'sit' & /wanka/ 'teeth' & - \\
\hline 22 & /ng/ & /ngela/ 'clean' & /tango/ 'be able' & - \\
\hline 23 & $/ \mathrm{mb} /$ & /mbali/ 'can' & /lambu/ 'house' & - \\
\hline 24 & $/ \mathrm{mp} /$ & /mparigi/ 'road' & /tumpo/ 'cut' & - \\
\hline 25 & /nt/ & /ntara/'defense' & /ĝunteli/ 'egg' & - \\
\hline 26 & $/ \mathrm{nd} /$ & /ndawu/ 'fall' & /founda/ 'cook' & - \\
\hline
\end{tabular}

Ana, H. (2019). A comparative study of Mawasangka and Wakatobi language in South East Sulawesi. International Research Journal of Management, IT and Social Sciences, 6(5), 226-233. https://doi.org/10.21744/irjmis.v6n5.733 


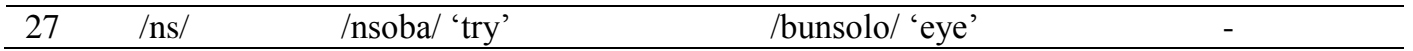

The consonant and cluster distribution above shows that consonant phoneme can place in the initial and medial, except phoneme / $\mathrm{j} /$ that place only on medial position. Besides, in the final position is only placed by vowel, or there is not any consonant that place in the final position. It means that Mawsangka is vocalist language. Related to the cluster, the first phoneme/sound is always nasal that is followed by plosive sounds, except $/ \mathrm{ns} /$ that is followed by fricative sound. In other words, the clusters are in the form of homorganic prenasal sequences in the initial and medial positions.

b) The Phonemes of Wakatobi Language

Wakatobi language as Mawasangka language also has five vowel phonemes are $/ \mathrm{i} /, / \mathrm{u} /, / \mathrm{e} /, / \mathrm{o} /$, and $/ \mathrm{a} /$. Further, the vowel phoneme distribution of Wakatobi language can be seen in the table (4) below.

Table 4

Vowel phoneme distribution of Wakatobi language

\begin{tabular}{lllll}
\hline No. & Phoneme & Initial & Medial & Final \\
\hline 1 & /a/ & /ana/ 'child' & /baliu/ 'buy' & /oliha/ 'scorpion' \\
2 & /i/ & /ido/ 'live' & /oliha/ 'scorpion' & /gonti/ 'cut' \\
3 & /u/ & /ukumaho/ 'breath' & /hunua/ 'bouse' & /baliu/ 'buy' \\
4 & /e/ & /ela/ 'tongue' & /kede/ 'sit' & /obue/ 'withdraw' \\
5 & /o/ & /obue/ 'withdraw' & /aropa/ 'front' & /marino/ 'silent' \\
\hline
\end{tabular}

The examples on table 4 show that the distribution of vowel phonemes categorized as completed distribution since it maybe existed in the initial, medial, and final of word. As Mawasangka language, Wakatobi has long vowel sounds. In communication, the short and long sound pronounced by the speaker does not disturb or influence the meaning or understanding of utterances. Vowel /a/ sometimes realized as [a:] as allophone of phoneme /a/, such as in words karaja: 'work' and bala: 'disaster'. Likewise, phoneme /o/ sometimes realized as [o:], such as in words olo: 'day' and moho: 'sick'; phoneme /i/ sometimes realized as [i:] such as in words mi:ina 'not' and mohi: 'left'; and phoneme / $\varepsilon /$ sometimes realized as [ $\varepsilon:]$ such as in words he:le 'spit'.

Further, there are 20 consonant phonemes in Wakatobi language are $/ \mathrm{b} /, / \mathrm{b} /, / \mathrm{p} /, / \mathrm{d} /, / \mathrm{d} /, / \mathrm{t} /, / \mathrm{g} /, / \mathrm{g} /, / \mathrm{k} /, / \mathrm{j} /, / \mathrm{g} /, / \mathrm{m} /$, $/ \mathrm{n} /, / \mathrm{f} /, / \mathrm{s} /, / \mathrm{h} /, / \mathrm{l} /, / \mathrm{r} /, / \mathrm{y} /$, and $/ \mathrm{w} /$; and 7 clusters are $/ \mathrm{ns} /, / \mathrm{nt} /, / \mathrm{nd} /, / \mathrm{mb} /, / \mathrm{nk} /, / \mathrm{ng} /$, and $/ \mathrm{mp} /$ as in the table (5) below.

Table 5

Consonant phoneme distribution of Wakatobi language

\begin{tabular}{|c|c|c|c|c|}
\hline No. & Fonem & Posisi Awal & Posisi Tengah & Posisi Akhir \\
\hline 1 & $/ \mathrm{b} /$ & /bahu/'shoulder' & /hobu/ 'dog' & - \\
\hline 2 & $/ \mathrm{d} /$ & /doho/ 'pressure' & /kede/ 'sit' & - \\
\hline 3 & /f/ & /feo/ 'press' & /kafi/ 'marry' & - \\
\hline 4 & /g/ & /gopo/ 'smoke' & /pogau / 'talk' & - \\
\hline 5 & $/ \mathrm{h} /$ & /hobu/ 'dog' & /doho/ 'pressure' & - \\
\hline 6 & /j/ & /jaygu / 'beard' & /karaja:/ ‘work’ & \\
\hline 7 & $/ \mathrm{k} /$ & /kede/ 'sit' & /ukumaho/ 'breath' & - \\
\hline 8 & /1/ & /lima/ 'hand' & /wila/ 'walk' & - \\
\hline 9 & $/ \mathrm{m} /$ & /marino/ 'silent' & /lima/ 'hand' & - \\
\hline 10 & $/ \mathrm{n} /$ & /nayku/ 'chew & /hunua/ 'house' & - \\
\hline 11 & $/ \mathrm{p} /$ & /pogau / 'talk’ & /gopo/ 'smoke' & - \\
\hline 12 & $/ \mathrm{r} /$ & /reke/ 'count' & /karaja:/ 'work' & - \\
\hline 13 & /s/ & /siasa/ 'beat' & /miso / 'suck’ & - \\
\hline 14 & $/ \mathrm{t} /$ & /ta:de/ 'stand' & /ito/ 'cry' & - \\
\hline 15 & $/ \mathrm{w} /$ & /wila/ 'walk' & /awu/ 'grit' & - \\
\hline 16 & /6/ & /6ali/ 'turn' & /to6ea/ 'harvest' & - \\
\hline 17 & /d/ & /dara-dara/'pigeon' & /ido/'live' & - \\
\hline 18 & $/ \hat{\mathrm{g}} /$ & /ĝorau/'egg' & padaga 'seller' & - \\
\hline
\end{tabular}




\begin{tabular}{lllll}
\hline 19 & /y/ & /yijo/ 'green' & /eyae/ 'not' & - \\
20 & $/ \mathrm{y} /$ & / nusu/ 'mouth' & /talina/ 'ear' & - \\
21 & $/ \mathrm{nk} /$ & /nkoe- ykoe/ 'kind of tiny fish' & /panku/ 'back' & - \\
22 & $/ \mathrm{ng} /$ & /ngae/ 'hang' & /wenka/ 'cleave' & - \\
23 & $/ \mathrm{mb} /$ & /mbale/ 'lie down' & /komba/ 'moon' & - \\
24 & $/ \mathrm{mp} /$ & /mpu:/ 'really' & /kompo/ 'abdoment' & - \\
25 & $/ \mathrm{nt} /$ & /ntona/ 'center' & /mentui/ 'suitable' & - \\
26 & $/ \mathrm{nd} /$ & /ndualo/ 'two days later' & /mondilu/ 'sour' & - \\
27 & $/ \mathrm{ns} /$ & - & /mansuana / 'Mr' & - \\
\hline
\end{tabular}

The consonant and cluster distribution above shows that consonant phoneme can place in the initial and medial, except cluster /ns/ that place only on medial position. Besides, in the final position is only placed by a vowel, or there is not any consonant that place in the final position. It means that Wakatobi is also categorized as vocalist language. Related to the cluster, the first phoneme/sound is always nasal that is followed by plosive sounds, except /ns/ that is followed by fricative sound. In other words, the clusters are in the form of homorganic prenasal sequences in the initial and medial positions.

Based on the description above, Mawasangka and Wakatobi languages have many similarities in terms of phoneme and its distribution. Both languages have five similar vowels are /a/, /i/, /u/, /e/, and /o/, and 20 similar consonant phonemes are /b/, /b/, /p/, /d/, /d/, /j/, /t/,/g/, /g/, /k/, /m/, /n/, /g/, /f/, /s/, /h/, /1/,/r/, /y/, and /w/, and 7 clusters are /ns/, $/ \mathrm{nt} /, / \mathrm{nd} /, / \mathrm{mb} /, / \mathrm{gk} /, / \mathrm{ng} /$, and $/ \mathrm{mp} /$. Besides, syllable of Mawasangka and Wakatobi languages always ended by vowel or opened that shows that both languages are vocalist. Besides, Both languages have long vowel sounds, in which the realization of the long sound is not phoneme, instead of phonetics only.

\subsection{Phonological Correspondence and Cognate Percentage of Mawasangka and Wakatobi Languages}

Mawasangka and Wakatobi languages have several phonological correspondences. The correspondence can be seen in Table 6.

Table 6

Phoneme Correspondence of Mawasangka Language (ML) and Wakatobi Language (WL)

\begin{tabular}{|c|c|c|c|c|}
\hline \multirow[t]{2}{*}{ No. } & \multirow{2}{*}{$\begin{array}{l}\text { Phoneme } \\
\text { Correspondence }\end{array}$} & \multicolumn{3}{|c|}{ Examples } \\
\hline & & $\mathrm{ML}$ & WL & Gloss \\
\hline 1. & $/ \mathrm{h} /-/ \mathrm{r} /$ & $\begin{array}{l}\text { hato } \\
\text { fekihi } \\
\text { hou } \\
\text { ho'o } \\
\text { gaha } \\
\text { \{no\}hondo } \\
\text { hea }\end{array}$ & $\begin{array}{l}\text { rato } \\
\text { fekiri } \\
\text { rou } \\
\text { ro'o } \\
\text { gara } \\
\{\text { mo }\} \text { rondo } \\
\text { raha }\end{array}$ & $\begin{array}{l}\text { come } \\
\text { think } \\
\text { drink } \\
\text { leaf } \\
\text { salt } \\
\text { night } \\
\text { blood }\end{array}$ \\
\hline 2. & /f/-/h/ & $\begin{array}{l}\text { nifi } \\
\text { golifa } \\
\text { tofa } \\
\text { fotu } \\
\text { febuni } \\
\text { fute } \\
\text { nifi }\end{array}$ & $\begin{array}{l}\text { nihi } \\
\text { oliha } \\
\text { toha } \\
\text { hotu } \\
\text { hebuni } \\
\text { hute } \\
\text { nihi }\end{array}$ & $\begin{array}{l}\text { thin } \\
\text { centipede } \\
\text { wash } \\
\text { head } \\
\text { hidden } \\
\text { white } \\
\text { dream }\end{array}$ \\
\hline 3. & /b/-/w/ & $\begin{array}{l}\text { robine } \\
\text { abu } \\
\text { buou } \\
\text { kabenkala }\end{array}$ & $\begin{array}{l}\text { howine } \\
\text { awu } \\
\text { woou } \\
\text { wilanka }\end{array}$ & $\begin{array}{l}\text { women } \\
\text { dust } \\
\text { new } \\
\text { step }\end{array}$ \\
\hline 4. & $/ \mathrm{d} /-/ \mathrm{j} /$ & $\begin{array}{l}\text { ido } \\
\text { danku } \\
\text { karada }\end{array}$ & $\begin{array}{l}\text { ijo } \\
\text { jangu } \\
\text { karaja: }\end{array}$ & $\begin{array}{l}\text { green } \\
\text { beard } \\
\text { work }\end{array}$ \\
\hline
\end{tabular}

Ana, H. (2019). A comparative study of Mawasangka and Wakatobi language in South East Sulawesi. International Research Journal of Management, IT and Social Sciences, 6(5), 226-233. https://doi.org/10.21744/irjmis.v6n5.733 


\begin{tabular}{|l|l|l|l|l|}
\hline & & $\begin{array}{l}\text { dari } \\
\text { tadi }\end{array}$ & $\begin{array}{l}\text { jari } \\
\text { taji }\end{array}$ & $\begin{array}{l}\text { net } \\
\text { cock's pur }\end{array}$ \\
\hline 5. & le/-/a/ & pandeha:ne & kudahanie & know \\
& & hea & raha & blood \\
& & mia & person \\
& & nea & naa & name \\
& & wuta & land \\
& & wite & asa \\
& & bali & turn \\
\hline
\end{tabular}

Based on table 6 above, consonant phonemes of Mawasangka and Wakatobi languages have perfected correspondence since it occurs to most data of both languages. Phoneme $/ \mathrm{h} /$ on ML correspondences to phoneme $/ \mathrm{r} /$ on WL in ultimo and penultymo positions. Besides, phoneme /f/ on ML correspondences to phoneme /h/ on WL in ultimo and penultymo positions, phoneme /b/ on ML correspondences to phoneme /w/ on WL, and phoneme / $\mathrm{d} /$ on ML correspondences to phoneme /j/ on WL in ultimo and penultymo positions. Further, it is also found the vowel correspondence. However, vowel correspondence is less than consonant correspondence. Vowel phoneme /e/ on ML correspondences to phoneme /a/ on WL in ultimo and penutylmo positions. All law happen on all linguistics data with any condition. In other words, the law is consistent with all linguistics data found in both languages in ultimo and penultymo positions.

Moreover, based on the counting of lexicostatistic technique by using 200 Swadesh lists found that Mawasangka and Wakatobi languages have closed relationship. The result of the lexicostatistic counting shows the cognate percentage Mawasangka language and Wakatobi language is $43.43 \%$. The percentage shows that Mawasangka and Wakatobi are categorized as different languages with a closed relationship in a language family, that is Muna-ButonWakatobi subgroup.

Those qualitative (phonological correspondence) and quantitative (lexicostatistic counts) evidence shows that Mawasangka and Wakatobi have genetic relationship. Although both languages are located and used in different regencies and are separated by the sea, Mawasangka and Wakatobi have many similarities, either in the phonology of lexical aspect.

\section{Conclusion}

The comparative study of Mawasangka and Wakatobi languages shows that both languages have closed relationship. The evidence has been given and explained either in qualitative or quantitative way. Based on the phoneme descriptions, it concludes that Mawasangka and Wakatobi languages have five similar vowels, they are /a/,

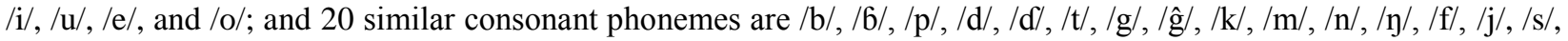
$/ \mathrm{h} /, / \mathrm{l} /, / \mathrm{r} /, / \mathrm{y} /$, and $/ \mathrm{w} /$; and even 8 similar clusters are $/ \mathrm{ns} /, / \mathrm{nt} /, / \mathrm{nd} /, / \mathrm{mb} /, / \mathrm{nk} /, / \mathrm{ng} /$, and $/ \mathrm{mp} /$. Besides, the words in Mawasangka Tongkuno and Wakatobi languages always ended by vowel or opened that shows that both languages are vocalist. Further, both languages have perfected phoneme correspondences, particularly for consonant phonemes. The quantitative approach by using lexicostastics technique shows that cognate percentage of Mawasangka and Wakatobi languages in the amount of $43.43 \%$ which is categorized as different languages with closed relationship in a language family.

\section{Conflict of interest statement}

The authors declared that they have no competing interest.

\section{Statement of authorship}

The authors have a responsibility for the conception and design of the study. The authors have approved the final article.

\section{Acknowledgments}

The author would like to thank to the Teacher Training and Educational Faculty of Halu Oleo University and Indonesia Study Department for giving permission and help in this project, and all who contributed so much of their time and ideas, especially to Dr. La Ino and Dr. Maulid Taembo, for their critical comments and suggestions for the improvement of this paper. Remaining errors are all mine. 


\section{References}

Bynon, T. (1979). The ergative construction in Kurdish. Bulletin of the School of Oriental and African Studies, 42(2), 211-224. https://doi.org/10.1017/S0041977X0014577X

Chaer, A. (2003). Seputar tata bahasa baku bahasa indonesia. Rineka Cipta.

Crowley, T. (1992). A dictionary of Paamese. Department of Linguistics, Research School of Pacific Studies, The Australian National University.

Crowley, T., \& Bowern, C. (2010). An introduction to historical linguistics. Oxford University Press.

Dyen, I. (2018). Linguistic subgrouping and lexicostatistics (Vol. 175). Walter de Gruyter GmbH \& Co KG.

Finegan, E., Besnir, N., Blair, D., \& Collins, P. (1992). Language Its Structure and Use. Marricksville.

Hafsah, W. O. S. (2017). The character education meaning on rites before wedding party in Muna ethnic of Southeast Sulawesi. International Research Journal of Management, IT and Social Sciences, 4(1), 32-38.

Ino, L., Dinar, S. S., Yunus, -, \& Harmin, -. (2017). Survival Wolio language in adulthood in Baubau City: Sociolinguistic study. International Journal of Linguistics, Literature and Culture, 3(6), 1-13.

Keraf, G. (1991). Linguistik Bandingan Historis, Jakarta: PT. Gramedia Pustaka Utama.

Kooij, J. G., \& Dik, S. C. (1994). Ilmu Bahasa Umum, terj. TW Kamil. Jakarta: RUL.

Lehmann, W. P. (2013). Historical linguistics: an introduction. Routledge.

Mahsun, M. S. (1995). Dialektologi diakronis: sebuah pengantar. Gadjah Mada University Press.

Poedjosoedarmo, S. (2008). Perubahan Bahasa. In Disajikan dalam Seminar Ceramah Ilmiah Linguistik Pusat Kajian Melayu. Surakarta: Universitas Sebelas Maret.

Sudaryanto. (1993). Metode dan aneka teknik analisis bahasa: pengantar penelitian wahana kebudayaan secara linguistis. Duta Wacana University Press.

Taalami, L. O. (2008). Mengenal Kebudayaan Wakatobi. Jakarta: Granada.

Yani, L., Artawa, K., Satyawati, N. M. S., \& Udayana, I. N. (2018). Transitivity construction of verbal clause in Ciacia language. International Journal of Linguistics, Literature and Culture, 4(3), 15-23.

Ana, H. (2019). A comparative study of Mawasangka and Wakatobi language in South East Sulawesi. International Research Journal of Management, IT and Social Sciences, 6(5), 226-233. https://doi.org/10.21744/irjmis.v6n5.733 